\title{
INTEGRATION OF SMART CLASS CONTROL SYSTEM USING AMAZON ECHO DOT WITH ARTIFICIAL NEURAL NETWORKS
}

\author{
Teddy Januar, Abd. Rabi, Dwi Arman Prasetya \\ Teknik Elektro, Universitas Merdeka Malang \\ Jl. Taman Agung, Karangbesuki, Kec. Sukun, Kota Malang, Jawa Timur 65146 \\ Email : Januarteddy.301@gmail.com
}

\begin{abstract}
Development of a class resource system that is integrated with the system that is the application-based system. One system that can be used is the Smart Class. Smart Class is a system that offers control of electronic equipment in the classroom using voice command control with a device that is Smart Speaker called Amazon echo dot which is used to facilitate the use of electronic devices in classrooms using Raspberry Pi Microcontroller technology by embedding smart class artificial neural network technology. With maximum performance at $1500 \mathrm{~ms}$ to $2000 \mathrm{~ms}$ on all conditions both sensors and actuators by iterating simultaneously 500 times with two hidden layers and the number of cells of each hidden layer is 9 and 5.
\end{abstract}

Keywords: Smart class, Artificial Neural Network, Raspberry Pi.

\section{Pendahuluan}

perkembangan ilmu pengetahuan dan teknologi dewasa ini semakin meningkatkan pula daya kreatifitas manusia yang memacu pekembangan teknologi yang bermanfaat dan berguna dalam mempermudah segala aktivitas manusia. khususnya pada bidang elektronika. Hal ini ditandai dengan munculnya berbagai peralatan yang diciptakan dan dapat dioperasikan secara manual maupun otomatis[1][2]. Dengan kemajuan teknologi ini maka berkembanglah suatu ilmu yang merupakan pemecah dari ilmu elektronika yakni dalam bidang sistem kontrol. Sistem ini dapat diartikan sebagai suatu sistem yang dapat bekerja secara otomatis maupun dengan perintah manusia. Saat ini system control banyak digunakan dalam kehidupan masyarakat[3][4]. Bahkan dalam tahun belakangan ini semakin banyak model system control yang semakin canggih.

Semakin berkembangnya proses pembelajaran di sebuah jenjang pendidikan terutama dalam sebuah universitas maka akan semakin dibutuhkan pula sebuah sistem yang lebih canggih dalam mendukung sarana pembelajaran. Sistem tersebut harus yang dapat digunakan dalam menyelesaikan berbagai persoalan dan masalah yang muncul seiring berkembangnya proses pembelajaran itu sendiri[5][6]. Oleh karena itu sebuah sistem yang didukung dengan sangat diperlukan untuk mendukung proses belajar, karena persiapan kelas masih dilakukan oleh manusia maka dari itu diperlukan untuk meningkatkan berbagai kesalahan yang disebabkan oleh kelalaian manusia itu sendiri, yang diproses proses alat di dalam ruang kelas akan memakan waktu lama dan menganggu proses perkuliahan[7][8]. Melihat hal tersebut maka perlu dikembangkan sebuah sistem sumber daya kelas yang terintegrasi dengan sistem yang berbasis aplikasi. Salah satu sistem yang dapat digunakan untuk memenuhi kebutuhan tersebut adalah Smart Class.

Smart Class merupakan sistem yang menawarkan kendali peralatan elektronik yang ada di dalam ruang kelaas atau ruang perkuliahan menggunakan kontrol perintah suara dengan suatu alat yang dikenal sebagai Smart Speaker yang dinamakan Amazon echo dot yang dipakai untuk mempermudah pengunaan perangkat elektronik di ruang kelas. Hubungaan antara kesiapan pengguna ruang kelas atau ruang perkuliahan dengan control fasilitas perangkat elektronik yang ada didalam ruang kelas di terapkan sebagai otomatisasi sistem 
Smart Class yang menggunakan koneksi internet. Berdasarkan penjelasan diatas maka dibuatlah penelitian dengan judul Sistem Kendali Smart Class Menggunakan Amazon Echo Dot Dengan Metode Neural Network yang menggunakan teknologi Mikrokontroller Raspberry $P i$ melalui Amazon echo dot sebagai pengirim dan penerima sinyal perintah[9][10]. Sistem control ini di harapkan dapat menambahkan wawasan pengetahuan bagi semua orang dalam mengikuti pekembangan teknologi elektronika dan juga memudahkan dalam proses pembelajaran di lingkungan pendidikan.

\section{Metodologi Penelitian}

Dalam perancangan dan pembuatan alat terdapat parameter yang digunakan. Dalam pengujian yang bertujuan untuk mengetahui kualitas dari perancangan yang akan diteliti dan di analisis dengan harapan bisa diperoleh data-data mengenai kinerja alat yang bermanfaat untuk ke depannya. Akurasi merupakan besaran persentase akurasi Neural Network dalam melakukan pengolahan data yang telah ditangkap oleh Amazon echo dot untuk mengaktifkan perangkat sesuai dengan perintah[11][12].

Diagram alir adalah bagan yang menunjukkan suatu alur kerja dari smart room yang sedang dikerjakan pada suatu sistem secara keseluruhan dan menjelaskan mengenai urutan dari prosedur yang ada didalam system smart room[13]. Adapun perancangan sistem yang dibuat terlihat pada gambar 1 .

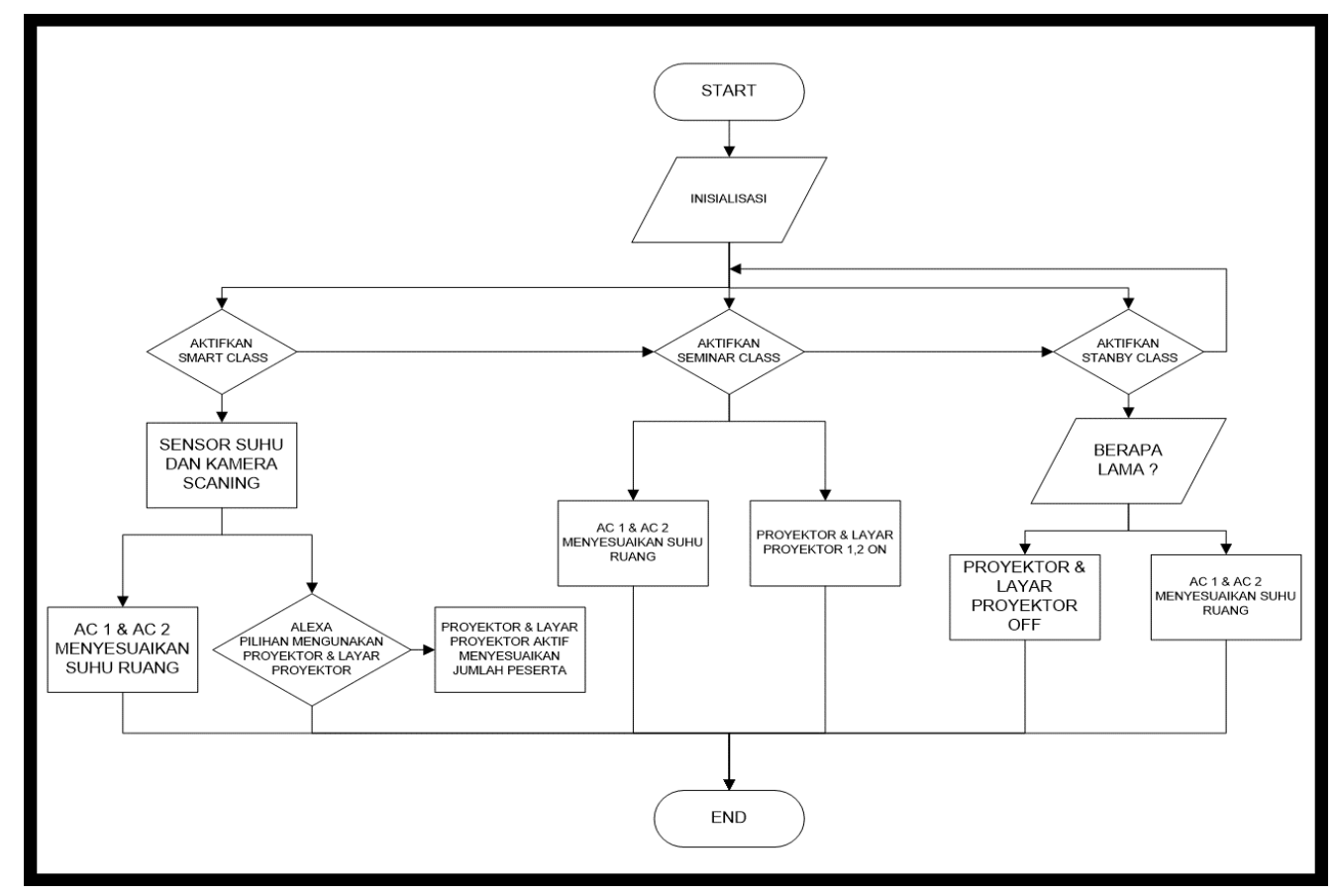

Gambar 1. Flowchart Sistem Kendali Smart Class

Pada Gambar 1. di jelaskan alur di mulai dari start kemudian di lakukan inisialisasi yang mana user akan di berikan 4 pilihan mode class oleh Amazon echo dot. Aktifkan smart class : Aktikan smart class dimana pada perintah ini di butuhkan waktu 2 menit untuk mempersiapkan proses scaning camera dan sensor suhu, dimana dalam perintah ini sensor suhu dan kamera akan melakukan scaning suhu ruangan dan jumlah peserta guna untuk menyesuaikan pengunaan peralatan AC 1, AC 2, layar proyektor 1, layar proyektor 2, proyektor 1, proyektor 2 secara otomatis tergantung kegunaan atau jumlah peserta yang ada di dalam ruang kelas. Aktifkan seminar class : Aktifkan seminar class dimana dalam perintah ini sensor suhu akan melakukan scaning suhu ruangan guna untuk menyesuaikan pengunaan 
AC 1, AC 2 tergantung dengan jumlah peserta yang ada di dalam ruang kelas, untuk layar proyektor 1, layar proyektor 2, proyektor 1, dan proyektor 2 akan hidup bersamaan. Aktifkan stanby class : Aktifkan stanby class mode ini digunakan pada waktu istirahat dimana user memberitahu Amazon echo dot mengenai berapa lama waktu istirahat di butuhkan guna mehindari error pada waktu proses scaning berlangsung. Ketika waktu istirahat sudah di tentukan maka proyektor 1, proyektor 2, layar proyektor 1, layar proyektor 2, akan off dan proses scaning sensor suhu dan camera akan dilakukan untuk menyesuaikan pengunaan AC 1 dan AC 2 sesuai dengan jumlah peserta yang ada di dalam ruang kelas. Pada saat waktu sudah selesai Amazon echo dot akan aktif kembali sesuai dengan mode awal yang di gunakan. Ada fitur tambahan, Aktifkan Smart Automatic Class yang di integerasikan dengan JST yang memenfaatkan CCTV/kamera video sebagai input

Pada bagian skematik rangkaian akan ditampilkan komponen yang dipakai untuk merancang perangkat agar saling terhubungkan. Desain skematik rangkaian hardware pada perangkat elektronik dengan control utama berupa raspberry pi dan Amazon echo dot difungsikan untuk menangkap perintah dari jaringan CCTV/kamera video sebagai input jaringan syraf tiruan untuk mendeteksi jumlah pengguna di dalam smart class dan memberikan keputusan yang diolah pada raspberry pi dan raspberry pi mengirimkan signal perintah melalui jaringan wifi ke ESP 8266 dan selanjutnya di lanjutkan kepada perangkat seperti Ac, layar proyektor, dan proyetor[14][15].

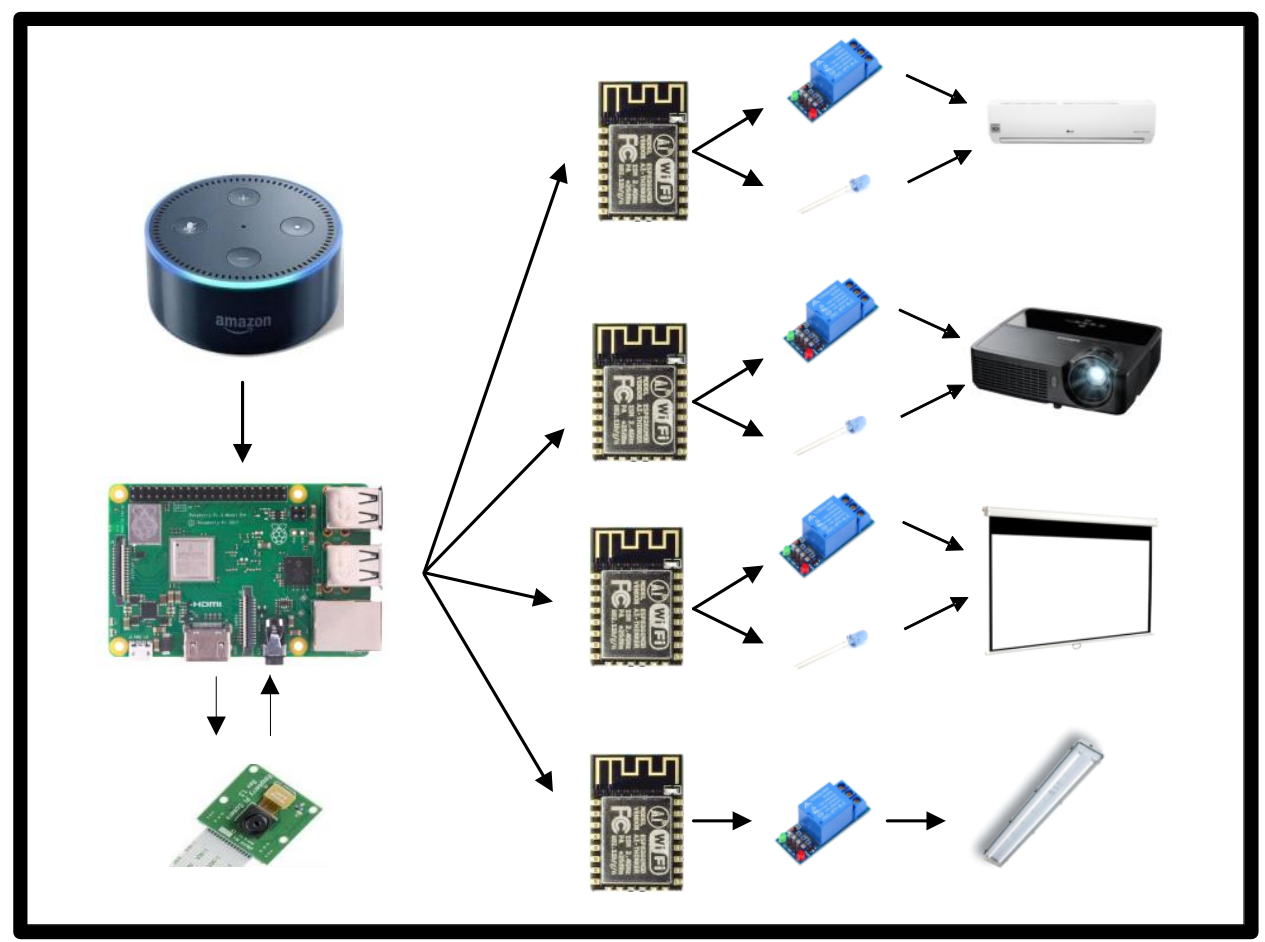

Gambar 2. Skematik Perancangan Sistem kendali Smart Class

Gambar 2 Menunjukkan perancangan hardware raspberry pi sebagai mini pc, Amazon echo dot dihubungkan pada raspberry pi yang tersedia, ESP 8266 dan relay yang sudah include pada board slave controler, selain menggunakan jaringan wifi yang selanjutnya dihubungkan menggunakan jaringan infrared, pin relay untuk perangkat tambahan yang dihubungkan ke pin GPIO pada raspberry pi[16][17]. 


\section{Hasil dan Pembahasan}

Peneliti melakukan analisis yang berfokus pada Jaringan syraf tiruan sebagai fitur dari alat yang di implementasikan, dengan mengambil dataset CCTV/Vidio kamera pada ruangan smart class, administrator pembagi data, administrator Jaringan syaraf tiruan untuk traning data berbasis complex objective yang kemudian diterapkan melalui administrator penerapan model dengan menggunakan data real, dan dilanjutkan ke dalam administrator performansi yang digunakan untuk mengukur instrument pengujian yang di perlihatkan pada gambar 3 .

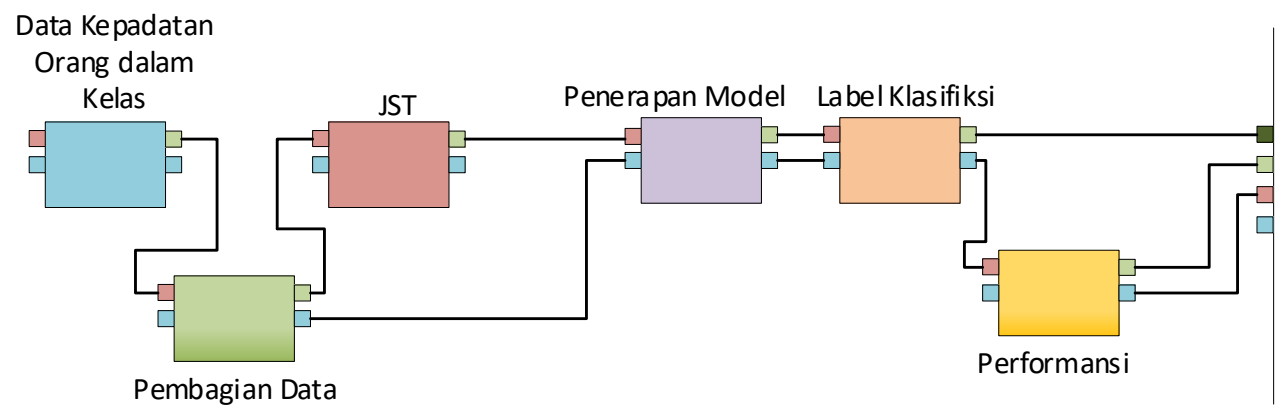

Gambar 3. Skematik sitem JST pada Smart Class

Pada penelitian smart class arsitektur JST yang digunakan terdiri dari 4 layer, yaitu layer input, Hidden layer pertama, Hidden layer kedua, dan Layer output[18][19]. Arsitektur jaringan saraf tiruan smart class diperlihatkan pada gambar 4. Implentasi model yang sudah fabrikasi dari data training untuk data uji dari smart class hingga mendapatkan tingkat akurasinya dengan semua instrumentasi yang ada kemudian dicatat hasilnya[20][21]. Implementasi struktur yang sudah didapatkan dari data training untuk data uji dengan menghilangkan atributnya satu per satu mulai dari partisi-partisinya dan mencatat akurasinya.

Dataset yang sudah partisi menjadi dua bagian yaitu data training dan data pengujian, kemudian akumulasikan ke dalam administrator Neural Network[22][23]. Data training digunakan untuk menemukan model Neural yang nantinya akan digunakan untuk instrumentasi model pengujian. 


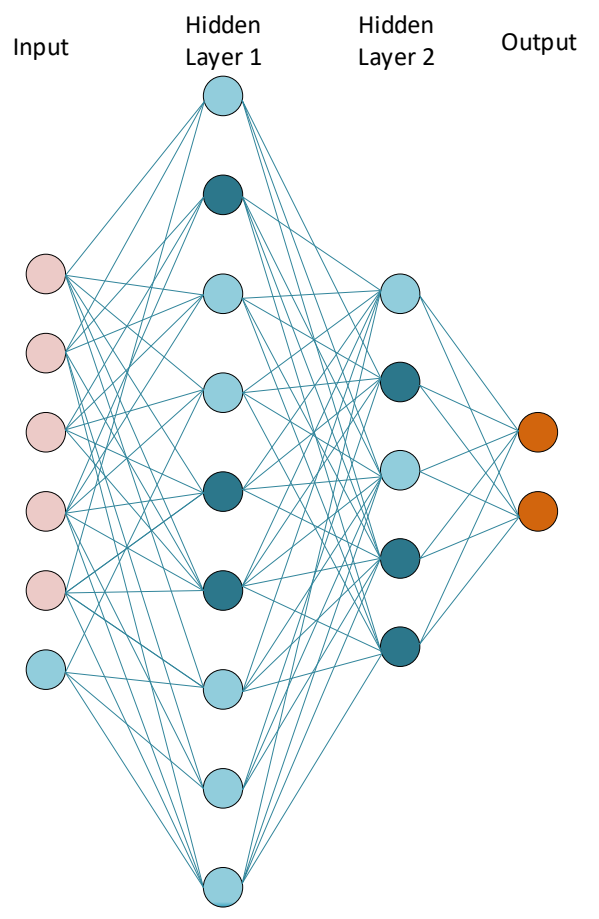

Gambar 4 Arsitektur JST pada Smart Class

Dengan menggunakan arsitektur JST pada Smart Class yang di tunjukkan pada gambar 4, JST Smart Class mengalami iterasi berulang sebanyak 500 kali dengan dua hidden layer secara simultan dan jumlah sel masing-masing hidden layer adalah sebanyak 9 dan 5. Nilai konstanta pada awal trining sebesar 0.2 dan momentum 0,8 , sedangkan toleransi error yang di perbolehkan sebesar 1.0E-6. Pada kondisi tersebut akurasi jaringan saraf tiruan pada Smart Class dengan menggunakan data pelatihan sebesar 98\%. sedengakan Intepretasi dari nilai JST pada Smart Class dapat di lihat pada grafik Kecepatan dan Akurasi Pengolahan Gambar yang dilakukan sejumlah 6 kali percobaan menggunakanJST pada Smart Class secara real dapat dilihat pada gambar 5 .

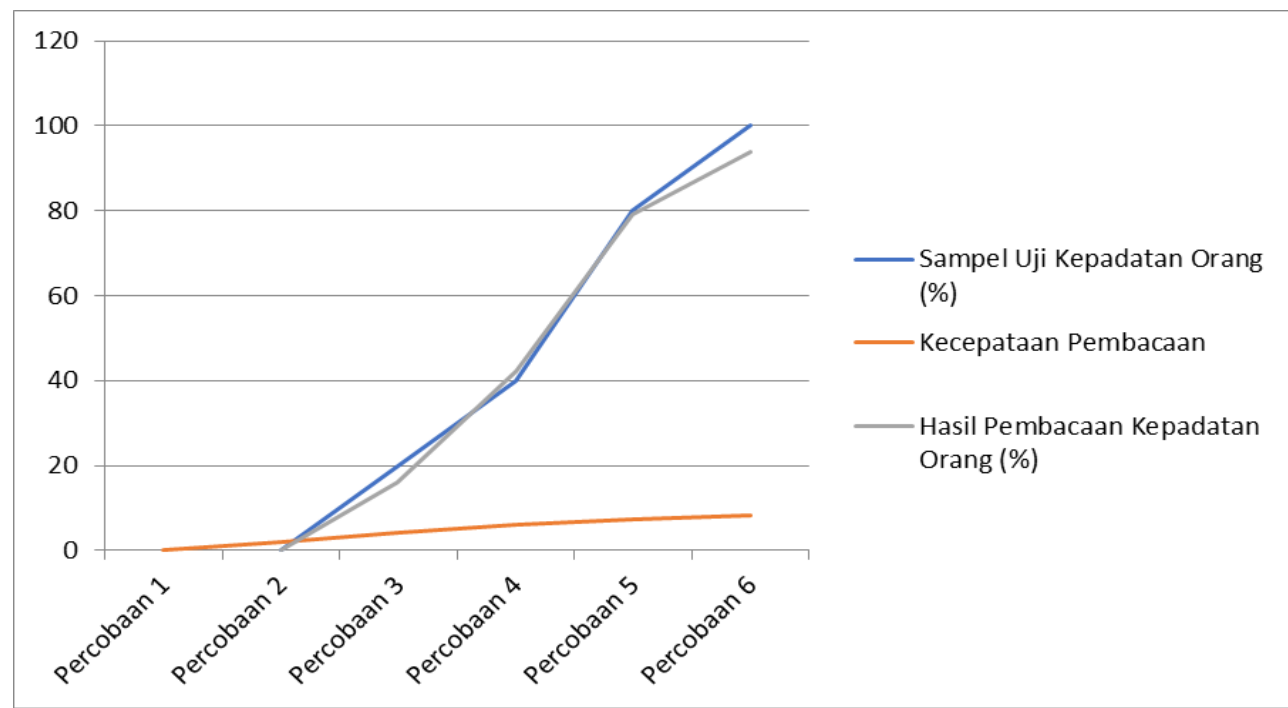

Gambar 5. Kecepatan dan Akurasi Pengolahan Gambar Pada Proses Perhitungan Orang Dalam Kelas 
Dari garafik tersebut di peroleh nilai maksimum pembacaan gambar dan prediksi yang di bandingan dengan kondisi real yaitu dibutuhkan waktu 8.1 sekon dengan maksimum pengguna ruang sebesar 94 orang dengan kursi ruang terisi penuh. Untuk mengetahui performansi dari raspberry pi maka dapat di deskripsikan mlalui tabel berikut dengan performansi alat yang telah di implementasikan secara real[24][25].

Tabel 1. Implemnatsi Uji Keberhasilan Pengiriman Data Dari Raspberry Ke ESP8266

\begin{tabular}{|c|c|c|c|c|c|}
\hline Percobaan & $\begin{array}{c}\text { Waktu } \\
\text { Tunda } \\
(\mathbf{m s})\end{array}$ & $\begin{array}{c}\text { ESP8266 } \\
\text { AC 1 }\end{array}$ & $\begin{array}{c}\text { ESP8266 } \\
\text { AC 2 }\end{array}$ & $\begin{array}{c}\text { ESP8266 } \\
\text { AC 3 }\end{array}$ & $\begin{array}{c}\text { ESP8266 } \\
\text { AC 4 }\end{array}$ \\
\hline $\mathbf{1}$ & $\mathbf{2 0 0}$ & Ok & Gagal & Ok & Gagal \\
\hline $\mathbf{2}$ & $\mathbf{5 0 0}$ & Gagal & Ok & Ok & Gagal \\
\hline $\mathbf{3}$ & $\mathbf{8 0 0}$ & Ok & Gagal & Ok & Ok \\
\hline 4 & $\mathbf{1 0 0 0}$ & Ok & Ok & Gagal & Ok \\
\hline 5 & $\mathbf{1 5 0 0}$ & Ok & Ok & Ok & Ok \\
\hline $\mathbf{6}$ & $\mathbf{2 0 0 0}$ & Ok & Ok & Ok & Ok \\
\hline 7 & $\mathbf{3 0 0 0}$ & Ok & Gagal & Ok & Ok \\
\hline
\end{tabular}

Dari tabel di atas dapat diketahui performansi dari raspberry pi yang telah di integerasikan ke ESP 8266 sebagai kendali sensor dan actuator untuk meproduksi output dari administrator JST Smart room dengan nilai maksimum waktu delay yang di butuhakan sebesar $1500 \mathrm{~ms}$ hingga 2000 ms pada kondisi on semua baik sensor maupun aktuator.

\section{Kesimpulan}

Integerasi Sistem Kendali Smart Class Menggunakan Amazon Echo Dot Dengan Jaringan Syaraf Tiruan memiliki tingkat kehandalan yang baik jika deilihat dari performansinya dengan nilai nilai maksimum pembacaan gambar dan prediksi yang di bandingan dengan kondisi real yaitu dibutuhkan waktu 8.1 sekon dengan maksimum pengguna ruang sebesar 94 orang dengan kursi ruang terisi penuh. Dan delay efektif sebesar $1500 \mathrm{~ms}$ hingga $2000 \mathrm{~ms}$ pada kondisi on semua baik sensor maupun actuator dengan melakukan proses iterasi secara simultan 500 kali dengan dua hidden layer secara simultan dan jumlah sel masing-masing hidden layer adalah sebanyak 9 dan 5. Nilai konstanta pada awal trining sebesar 0.2 dan momentum 0,8, sedangkan toleransi error yang di perbolehkan sebesar 1.0E-6.

\section{Daftar Pustaka}

[1] Gubbi, J., Buyya, R., Marusic, S., \& Palaniswami, M. (2013). Internet of Things (IoT): A vision, architectural elements, and future directions. Future generation computer systems, 29(7), 1645-1660.

[2] Janis, D. A., Pang, D., \& Wuwung, J. O. (2014). Rancang Bangun Robot Pengantar Makanan Line follower. Jurnal Teknik Elektro dan Komputer, 3(1), 1-10.

[3] Ngu, A. H., Gutierrez, M., Metsis, V., Nepal, S., \& Sheng, Q. Z. (2016). IoT middleware: A survey on issues and enabling technologies. IEEE Internet of Things Journal, 4(1), 1-20.

[4] Mujahidin, I., Pramono, S. H., \& Muslim, A. (2018, October). 5.5 Ghz Directional Antenna with 90 Degree Phase Difference Output. In 2018 Electrical Power, Electronics, Communications, Controls and Informatics Seminar (EECCIS) (pp. 224228). IEEE. 
[5] T. Jensen and M. Durham, "Internet of things," Advancing Microelectronics, 2017.

[6] Mujahidin, I., Hidayatulail, B. F., \& Arinda, P. S. (2019). 2.4 GHZ Square Ring Patch With Ring Slot Antenna For Self Injection Locked Radar. JEEMECS (Journal of Electrical Engineering, Mechatronic and Computer Science), 2(2), 39-44.

[7] Prakarsa, M. T., Wahyuni, D., Rachman, N., \& Mujahidin, I. (2019). Optimasi Sistem Komunikasi Dari HT Dengan HP Dalam Pelaksanaan Tugas Operasi Tni Ad Menggunakan Metode DTMF. JASIEK (Jurnal Apl. Sains, Informasi, Elektron. dan Komputer).

[8] Mujahidin, I. (2018). Directional $1900 \mathrm{MHz}$ Square Patch Ring Slot Microstrip Antenna For WCDMA. JEEMECS (Journal of Electrical Engineering, Mechatronic and Computer Science), 1(2), 42-45.

[9] Hartono, A. F., Dwijanto, D., \& Abidin, Z. (2012). Implementasi Jaringan Syaraf Tiruan Backpropagation Sebagai Sistem Pengenalan Citra Daging Babi dan Citra Daging Sapi. UNNES Journal of Mathematics, 1(2).

[10] Minggu, D., \& Mujahidin, I. (2019). Frequency Hopping Video Real Time Untuk Pengamanan Data Pengintaian Operasi Inteligence TNI. JASIEK (Jurnal Aplikasi Sains, Informasi, Elektronika dan Komputer), 1(1), 18-27.

[11] Khan, M. A., \& Salah, K. (2018). IoT security: Review, blockchain solutions, and open challenges. Future Generation Computer Systems, 82, 395-411.

[12] Lasmono, J., Sari, A. P., Kuncoro, E., \& Mujahidin, I. (2019). Optimasi Kerja Peluncur Roket Pada Robot Roda Rantai Untuk Menentukan Ketepatan Sudut Tembak. JASIEK (Jurnal Apl. Sains, Informasi, Elektron. dan Komputer).

[13] Sjogelid, S. (2015). Raspberry Pi for secret agents. Packt Publishing Ltd.

[14] Agrawal, N., \& Singhal, S. (2015, May). Smart drip irrigation system using raspberry pi and arduino. In International Conference on Computing, Communication \& Automation (pp. 928-932). IEEE.

[15] Yuwono, R., Mujahidin, I., \& Mustofa, A. (2015). Rectifier using UFO microstrip antenna as electromagnetic energy harvester. Advanced Science Letters, 21(11), 34393443.

[16] Bell, C. (2014). Beginning sensor networks with Arduino and Raspberry Pi. Apress.

[17] Mujahidin, I., Yuwono, R., \& Mustofa, A. (2015). Rancang Bangun Rectifier Antenna Mikrostrip Ufo Pada Frekuensi Ultra Wideband (UWB) Sebagai Pemanen Energi Elektromagnetik. Jurnal Mahasiswa TEUB, 3(2).

[18] Ramadhan, M. S., Novamizanti, L., \& Susatio, E. (2019). Sistem Pengenalan Individu Berbasis Citra Wajah 3D dengan Jaringan Syaraf Tiruan. Techné: Jurnal Ilmiah Elektroteknika, 18(01), 1-14

[19] Wilson, C., Hargreaves, T., \& Hauxwell-Baldwin, R. (2015). Smart homes and their users: a systematic analysis and key challenges. Personal and Ubiquitous Computing, 19(2), 463-476.

[20] Jiang, L., Liu, D. Y., \& Yang, B. (2004, August). Smart home research. In Proceedings of 2004 International Conference on Machine Learning and Cybernetics (IEEE Cat. No. 04EX826) (Vol. 2, pp. 659-663). IEEE.

[21] S. Davidoff, M. K. Lee, C. Yiu, J. Zimmerman, and A. K. Dey, "Principles of smart home control," in Lecture Notes in Computer Science (including subseries Lecture Notes in Artificial Intelligence and Lecture Notes in Bioinformatics), 2006

[22] Kubat, M. (2017). An introduction to machine learning (Vol. 2). Cham, Switzerland: Springer International Publishing.

[23] LeCun, Y., Bengio, Y., \& Hinton, G. (2015). Deep learning. nature, 521(7553), 436444.

[24] Seeger, M. (2004). Gaussian processes for machine learning. International journal of 
neural systems, 14(02), 69-106.

[25] Alam, M. R., Reaz, M. B. I., \& Ali, M. A. M. (2012). A review of smart homes-Past, present, and future. IEEE Transactions on Systems, Man, and Cybernetics, Part C (Applications and Reviews), 42(6), 1190-1203. 